\title{
MENINGKATKAN RASA EMPATI MELALUI BIMBINGAN KELOMPOK DENGAN TEKNIK BERMAIN PERAN (ROLE PLAYING) SISWA KELAS XI TKJ 3 DI SMK NEGERI 1 PACITAN TAHUN PELAJARAN 2020/2021
}

\author{
Diana Mayasari \\ SMK Negeri 1 Pacitan \\ bunda.diana.mayasari@gmail.com \\ Siti Mardiana Hindayati \\ SMK Al Kaaffah \\ sitimardianahindayati@gmail.com \\ Fitriana Dyah Wulandari \\ SMK Raden Patah Mojokerto \\ fitrididik2011@gmail.com \\ Etik Sulistyowati, S.Pd. \\ SMK Negeri 1 Jetis \\ etik.sulis@gmail.com \\ Fitrah Romadhoni Laily \\ SMK Negeri 1 Lumajang \\ fitra.rl@gmail.com
}

\begin{abstract}
Abstrak
Penelitian ini memakai metode bermain peran guna tingkatkan sikap siswa yang kurang mempunyai rasa empati. Penelitian ini memakai pendekatan kualitatif guna memperoleh informasi serta analisis lewat kajian- kajian reflektif, partisipasif. Pengembangan program didasarkan datadata serta data dari siswa dan setting sosial secara alamiah lewat 2 tahapan siklus penelitian tindakan. Guna meningkatkan rasa empati siswa dicoba dengan memakai metode role playing. Penelitian ini dicoba di kelas XI TKJ 3 SMK Negeri 1 Pacitan dengan 2 siklus. Pada siklus awal siswa belum bersungguh- sungguh dalam melaksanakan aktivitas, sehingga butuh dipaparkan lagi manfaat bermain peran ini, sehingga butuh diulang lagi sampai siklus kedua. Dari hasil observasi, kegiatan siswa dari $68 \%$ pada siklus awal, bertambah jadi $86 \%$ pada siklus kedua. Dengan demikian metode bermain peran dapat digunakan buat menaikkan empati siswa di kelas XI TKJ 3SMK Negeri 1 Pacitan.
\end{abstract}

Kata Kunci: Empati, Bermain Peran 
Bimbingan dan Konseling Universitas PGRI Adi Buana Surabaya

ISSN: 02162938

\section{Abstract}

This research uses role-playing techniques to improve the behaviour of students who lack empathy. This research uses a qualitative approach to obtain informasi and analysis through reflective, participatory studies. Program development is based on informasi and information from students and social settings naturally through two stage of the research cycle. To increase students' sense of empathy, role playing techniques are used. This research was conducted in class XI TKJ 3 SMK Negeri 1 Pacitan with two cycles. In the first cycle students have not been serious in carrying out activities, so it is necessary to explain again the uses and benefits of playing this role, so it needs to be repeated until the second cycle. From the results of observations, student activity increases from $68 \%$ in the first cycle, increasing to $86 \%$ in the second cycle. So the role playing method can be used to increase student empathy in class XI TKJ 3 of Sekolah Menengah Kejuruan (SMK) Negeri 1 Pacitan.

Keywords: Empathy, Role playing

\section{LATAR BELAKANG}

Pendidikan merupakan investasi hidup yang paling berharga yang dapat menciptakan SDM yang berkualitas, beriman, bertakwa kepada Tuhan YME, berbudi pekerti luhur untuk mencapai kemampuan yang tinggi.

Sesuai yang ada di dalam UU SPN NO 20 tahun 2003, bahwa pendidikan adalah usaha sadar untuk menyiapkan peserta didik melalui kegiatan bimbingan, pengajaran dan atau latihan yang bermanfaat di masa yang akan datang.

Dalam kegiatan bimbingan diharapkan dapat merubah perilaku siswa yang kurang berempati. Empati selalu disebut- sebut bagaikan resonansi dari perasaan. Secara fisika berarti turut bergetarnya sesuatu barang sebab persamaan frekuensi. Dengan empati seorang bakal menciptakan frekuensi perasaan dalam dirinya sama dengan frekuensi perasaan yang dialami orang lain.
Sehingga dia ikut bergetar, ikut menguasai sekalian merasakan apa yang dialami orang lain. Sebab bayangan, keyakinan serta kemauan seorang berhubungan dengan perasaannya, seorang yang berempati hendaknya sanggup mengenali benak serta mood orang lain.

Selama ini yang terjadi di SMK Negeri 1 Pacitan ternyata masih banyak perilaku siswa yang sering mengganggu teman tanpa rasa bersalah, dan dilakukan berulang kali. Dengan demikian kegiatan belajar akan terganggu. Selain itu sering terjadi konflik, perkelahian, meminta uang kepada teman, sehingga kegiatan belajar akan terganggu.

Maka dipandang perlu untuk meningkatkan rasa empati pada diri siswa. Salah satu cara yang dipandang efektif untuk merubah atau meningkatkan perilaku individu tersebut melalui teknik bermain peran. Oleh karena itu butuh dicoba penelitian dengan tujuan mengenali signifikansi peningkatkan 
Bimbingan dan Konseling Universitas PGRI Adi Buana Surabaya

ISSN: 02162938

rasa empati siswa dengan melakukan layanan bimbingan kelompok menggunakan metode bermain peran.

Metode role playing di pelopori oleh George Shaftel (B. Uno, Hamzah, 2010) merupakan salah satu bentuk metode mengajar yang digunakan untuk memperjelas materi pelajaran dengan cara menirukan suatu kegiatan yang sifatnya pura-pura/tidak nyata. Dimana saat pembelajaran di dalam kelas, seakan-akan siswa berada pada situasi di luar kelas.

Metode role playing merupakan sesuatu metode kemampuan bahan-bahan pelajaran lewat pengembangan imajinasi serta penghayatan siswa. Pengembangan imajinasi serta penghayatan dicoba siswa dengan memerankannya bagaikan tokoh hidup ataupun barang mati. Game ini biasanya dicoba lebih dari satu orang, perihal itu tergantung kepada apa yang diperankan. Tata cara ini bisa mengaitkan siswa berpartisipasi serta memiliki peluang buat memajukan kemampuannya dalam berkolaborasi (Hamalik, Oemar, 2005). Dengan role playing siswa akan merasakan belajar yang menyenangkan sehingga siswa akan menemukan pengalaman yang baru.

Dari penjelasan tersebut dapat disimpulkan bahwa role playing merupakan metode pembelajaran untuk menirukan kegiatan supaya siswa mendapat pengalaman baru dalam proses belajar.

Metode role playing ini ternyata juga dapat menumbuhkan rasa empati pada diri siswa yang menekankan keterlibatan emosional dalam situasi masalah. Dengan memainkan peran orang lain maka siswa akan memahami kondisi seseorang yang diperankan. Dengan teknik role playing mereka tidak akan dengan mudahnya menghakimi seseorang atau suatu masalah, kecuali terlebih dahulu melihat dari berbagai sudut pandang (Djamarah ,Syaiful Bahri, 2006).

Dengan role playing siswa bisa menghadapi serta merasakan jadi seseorang/ tokoh yang bisa di dengar dalam kehidupan mereka. Perihal ini bakal membuat mereka jadi lebih peka terhadap masalah-masalah yang terdapat di sekitarnya, tingkatkan keahlian interpersonal, serta bisa menambah rasa empati ( SM, Ismail, 2008).

\section{METODOLOGI}

Penelitian ini termasuk penelitian tindakan BK (PTBK) yang biasa disebut classroom action research yang mempunyai 4 aspek yang sangat berguna antara lain perencanaan, aksi, observasi, serta refleksi. Penelitian ini bertujuan untuk meningkatkan rasa empati siswa dengan pelaksanaan metode role playing di kelas XI TKJ 3 SMK Negeri 1 
Bimbingan dan Konseling Universitas PGRI Adi Buana Surabaya

ISSN: 02162938

Pacitan sebab rasa empati siswa di kelas tersebut sangat rendah.

Waktu penelitian ini dilaksanakan pada Semester Ganjil Tahun Pelajaran 2020/ 2021 yang bertempat di Kelas XI TKJ 3 SMK Negeri 1 Pacitan dengan sampel penelitian siswa kelas XI TKJ 3 SMK Negeri 1 Pacitan yang berjumlah 30 siswa terdiri dari 6 siswa perempuan serta 24 siswa laki-laki. Pemilihan kelas XI TKJ 3 sebagai subjek penelitian adalah berdasar pengamatan selama proses pembelajaran berlangsung, kelas XI TKJ 3 memiliki kondisi empati yang paling rendah. Empati yang rendah ditunjukkan dalam bentuk suasana kelas yang tidak kondusif sehingga proses pembelajaran tidak berjalan secara optimal. Hal ini ditandai seperti siswa mengobrol dengan temannya, sering tidak memperhatikan guru, tidak ada kemauan untuk bertanya, tidak bersemangat, serta cuma sedikit siswa yang ingin menanggapi persoalan dari guru dan tidak ingin berteman dengan sahabat di luar gengnya. Dengan dijadikannya kelas tersebut selaku subjek riset, sehingga diharapkan bisa terjalin kenaikan empati sesudah diterapkannya metode role playing.

Pada tahap perencanaan yang dilakukan peneliti adalah; (1) Menganalisis kompetensi dasar yang akan digunakan untuk layanan tindakan bimbingan dan konseling, (2) Membuat skenario role playing, (3)
Membuat LKPD, (4) Menyusun kisi-kisi (blue print) instrumen yang digunakan dalam siklus PTBK, (5) Menyusun perlengkapan penilaian/evaluasi proses dan hasil.

Pada tahap tindakan, peneliti memberikan tindakan dalam bentuk pelayanan bimbingan kelompok. Adapun tahapan yang dilakukan peneliti adalah: (1) Guru BK membentuk kelompok siswa menjadi 5 kelompok dimana tiap-tiap kelompok terdiri dari 6 siswa (2) Memberikan penjelasan tentang kompetensi yang akan dicapai, (3) Memanggil siswa yang sudah ditunjuk untuk melakonkan skenario yang sudah disiapkan, (4) Masing-masing siswa berada pada kelompoknya sambil mengamati skenario yang sedang diperagakan, (5) Setelah selesai ditampilkan masing-masing siswa diberi lembar kerja untuk membahas atas penampilan masing-masing kelompok, (6) Masing-masing kelompok menampilkan hasil kesimpulannya, (7) Guru BK memberikan kesimpulan secara umum, (8) Evaluasi, (9) Penutup.

Teknik analisis data yang digunakan adalah deskriptif kuantitatif dan deskriptif kualitatif dengan kategori-kategori kalimatkalimat.

\section{HASIL PENELITIAN}

Hasil riset dijelaskan dalam tahapan yang berbentuk siklus- siklus layanan 
bimbingan yang dilakukan di kelas. Dalam penelitian ini layanan bimbingan dilakukan dalam tiga siklus sebagaimana pemaparan berikut ini:

1. Siklus Pertama (I): Siklus pertama terdiri dari empat tahap yaitu perencanaan, tindakan, observasi dan refleksi.

a. Perencanaan, meliputi: (1) Menganalisis kompetensi dasar yang akan digunakan untuk layanan tindakan bimbingan dan konseling, (2) Membuat skenario role playing, (3) Membuat lembar kerja siswa, (4) Merancang instrumen yang digunakan dalam siklus PTBK, (5) Menyusun alat evaluasi.

b. Pelaksanaan. Disaat siklus awal pelaksanaan belum cocok dengan rencana, perihal ini diakibatkan: (1)

Sebagian kelompok belum bersungguhsungguh dalam melaksanakan peran yang terdapat pada skenario, (2) Sebagian kelompok lagi belum

c. Observasi serta Evaluasi

1) Hasil observasi kegiatan siswa dalam aktivitas bimbingan sepanjang siklus awal bisa dilihat pada tabel berikut:

Tabel I

Perolehan Skor Aktifitas Siswa dalam Kegiatan Bimbingan Siklus I

\begin{tabular}{|c|c|c|c|}
\hline Kelompok & $\begin{array}{c}\text { Skor } \\
\text { Perolehan }\end{array}$ & $\begin{array}{c}\text { Skor } \\
\text { Ideal }\end{array}$ & Prosentase \\
\hline 1 & 67 & 96 & $70 \%$ \\
\hline 2 & 63 & 96 & $66 \%$ \\
\hline 3 & 73 & 96 & $76 \%$ \\
\hline
\end{tabular}

memahami arti role playing dalam rangka upaya peningkatan rasa empati. Guna menanggulangi permasalahan di atas, maka dilakukan hal sebagai berikut: (1) Guru BK lebih intensif memberikan penjelasan kepada siswa bahwa dalam berkelompok butuh kerjasama serta partisipasi, (2) Guru BK membantu memberi pengertian empati yang dilatihkan melalui teknik role playing ini. Pada akhir siklus awal dari hasil pengamatan guru Bimbingan dan Konseling bisa disimpulkan antara lain: (1) Siswa mulai terbiasa dengan keadaan belajar berkelompok, (2) Siswa mulai memperlihatkan kepedulian, hasrat serta keseriusan dalam melaksanakan aktivitas role playing.

\begin{tabular}{|c|c|c|c|}
4 & 61 & 96 & $64 \%$ \\
\hline 5 & 60 & 96 & $63 \%$ \\
\hline Rerata & $\mathbf{3 2 4}$ & $\mathbf{4 8 0}$ & $\mathbf{6 8 \%}$ \\
\hline
\end{tabular}

\section{Grafik 1}

Perolehan Skor Aktifitas Siswa dalam Kegiatan Bimbingan Siklus I 


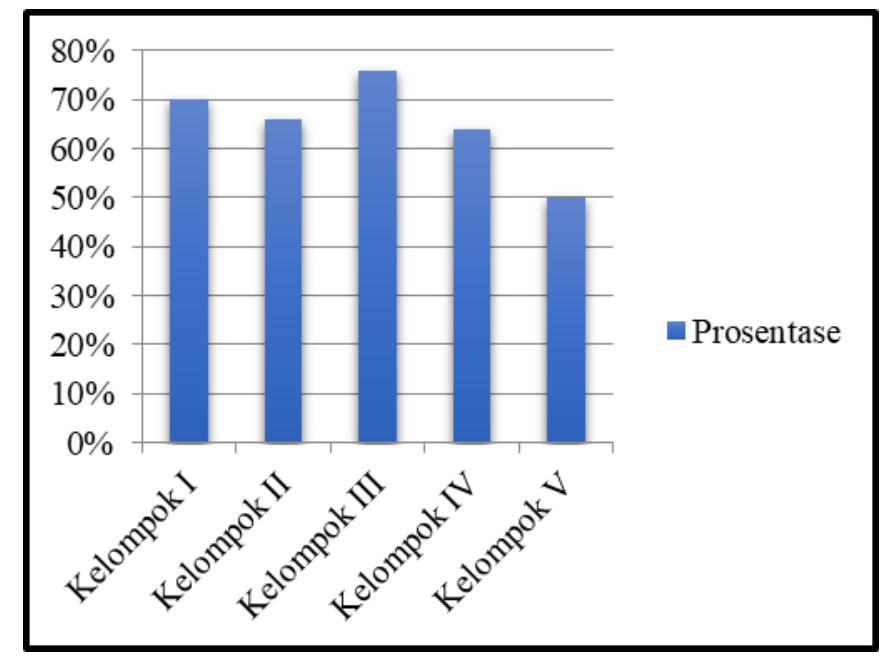

2) Hasil penilaian siklus 1 Kemampuan siswa terhadap modul layanan bimbingan.

Tidak hanya kegiatan siswa dalam aktivitas bimbingan, kemampuan siswa terhadap modul layanan belum menggapai kriteria keberhasilan yang ditetapkan yakni $70 \%$, rasa empati masih dalam kategori rendah dari skor sempurna $100 \%$, skor perolehan ratarata $68 \%$.

d. Refleksi dan Perencanaan Ulang. Keberhasilan dan kegagalan yang berlangsung pada siklus I disebabkan: (1) Sebagian siswa belum terbiasa belajar bermain peran, (2) Hasil evaluasi rata- rata masih rendah, (3) Siswa kurang bersungguh- sungguh dalam memainkan perannya. Guna memperbaharui kelemahan serta mempertahankan keberhasilan yang sudah dicapai pada siklus awal, untuk penerapan siklus kedua bisa membuat perencanaan yaitu: (1) Menyampaikan motivasi kepada kelompok supaya lebih aktif lagi dalam melaksanakan aktivitas bmbingan,( 2) Lebih intensif membimbing kelompok yang menghadapi kesusahan, (3) Memberikan pengakuan ataupun penghargaan

2. Siklus Kedua (II): Sama halnya dengan siklus I, siklus ke-II ini terdiri dari perencanaan, pelaksanaan/ tindakan, observasi serta refleksi dan replanning.

a. Perencanaan

Rencana pada siklus ke-II bersumber pada replanning siklus awal yakni:

1) Membagikan motivasi kepada kelompok supaya lebih aktif lagi dalam aktivitas layanan Bimbingan dan Konseling

2) Lebih intensif lagi membimbing kelompok yang menghadapi kesusahan

3) Memberi penghargaan

b. Pelaksanaan

1) Suasana kegiatan bimbingan sudah lebih baik. Tugas yang diberikan telah dikerjakan dengan baik oleh siswa, mereka saling bekerjasama dan terlihat lebih antusias dalam mengikuti dan melakukan perannya.

2) Siswa sudah memahami arti empati dalam kehidupan sehari-hari contoh 
seperti yang sudah diperankan oleh siswa tersebut

c. Observasi dan Evaluasi/penilaian

1) Adapun hasil observasi/pengamatan terhadap aktivitas siswa dalam kegiatan bimbingan selama siklus ke-II terlihat pada tabel berikut:

Tabel 2

Perolehan Skor Aktivitas Siswa dalam Kegiatan Bimbingan Siklus II

\begin{tabular}{|c|c|c|c|}
\hline Kelompok & $\begin{array}{c}\text { Skor } \\
\text { Perolehan }\end{array}$ & $\begin{array}{c}\text { Skor } \\
\text { Ideal }\end{array}$ & $\begin{array}{c}\text { Persentase } \\
(\%)\end{array}$ \\
\hline 1 & 83 & 96 & $86 \%$ \\
\hline 2 & 82 & 96 & $85 \%$ \\
\hline 3 & 81 & 96 & $84 \%$ \\
\hline 4 & 81 & 96 & $84 \%$ \\
\hline 5 & 84 & 96 & $88 \%$ \\
\hline Rerata & $\mathbf{4 1 1}$ & $\mathbf{4 8 0}$ & $\mathbf{8 6 \%}$ \\
\hline
\end{tabular}

\section{Grafik 2}

Perolehan Skor Aktivitas Siswa dalam Kegiatan Bimbingan Siklus II

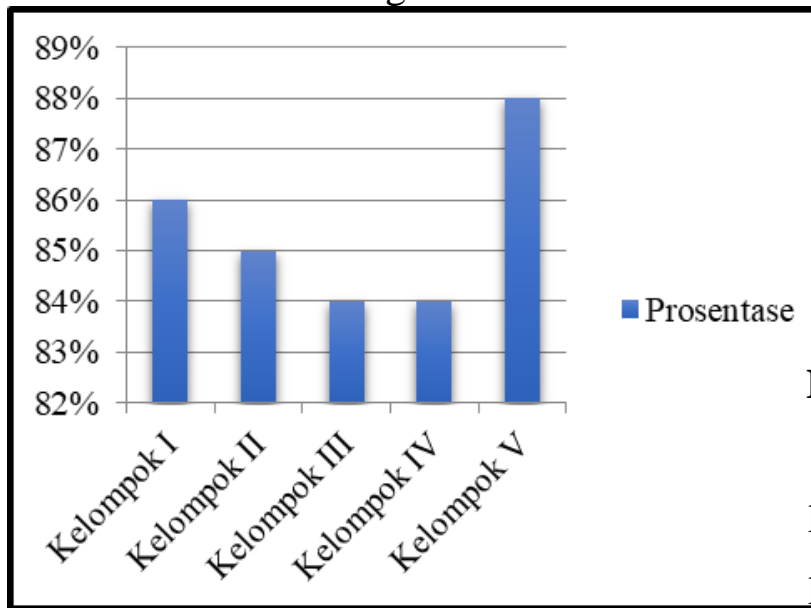

2) Hasil penilaian kemampuan siswa terhadap modul layanan bimbingan pada siklus ke-II ialah skor ideal $100 \%$ reratanya $86 \%$

d. Refleksi serta Perencanaan Ulang
Keberhasilan yang diperoleh pada siklus ke-II ini antara lain:

1) Kegiatan siswa dalam aktivitas bimbingan telah menguasai rasa empati serta telah sanggup membangun kerjasama dalam kelompok. Siswa sanggup berpartisipasi dalam aktivitas bimbingan dengan baik. Perihal ini bisa dilihat dari data yang diperoleh berdasarkan hasil observasi terhadap kegiatan siswa sudah bertambah, dari $68 \%$ pada siklus awal jadi $86 \%$ pada siklus kedua

2) Meningkatnya kegiatan siswa dalam melakukan penilaian terhadap keahlian siswa memahami modul layanan, perihal ini bersumber pada hasil penilaian $68 \%$ pada siklus awal bertambah jadi $86 \%$ pada siklus kedua.

\section{KESIMPULAN}

Bersumber pada hasil deskripsi serta paparan informasi sebagaimana dikemukakan pada ulasan bisa dikemukakan simpulan penelitian ialah pelaksanaan metode role playing bisa tingkatkan empati siswa di SMKN 1 Pacitan tahun pelajaran 2020/ 2021, terutama kelas XI TKJ 3. Upaya yang dilaksanakan buat tingkatkan empati siswa dengan melakukan 
Bimbingan dan Konseling Universitas PGRI Adi Buana Surabaya

ISSN: 02162938

metode role playing. Hasil penelitian ini menampilkan jika penerapan pendidikan dengan mempraktikkan metode role playing bisa tingkatkan empati siswa kelas XI TKJ 3 SMKN 1 Pacitan tahun pelajaran 2020/ 2021.

Perihal tersebut dibuktikan dengan terdapatnya kenaikan rata- rata persentase yang menunjukkan empati siswa tiap siklusnya. Pada siklus I rata- rata persentase empati siswa yaitu $68 \%$. Pada siklus II jadi $86 \%$ ataupun alami kenaikan sebesar $18 \%$. Perihal ini berarti kalau rata- rata persentase yang menunjukkan empati siswa sudah melampaui kriteria keberhasilan kegiatan yakni $70 \%$.

\section{SARAN}

Bersumber pada penelitian yang sudah dicoba, peneliti memiliki masukan yaitu:

1. Dalam proses pendidikan dengan mempraktikkan metode role playing, guru hendaknya lebih kreatif dalam mengajarkan modul serta lebih memotivasi siswa, sehingga tiap siswa lebih siap dalam menjajaki proses pendidikan memakai metode role playing..

2. Hendaknya metode role playing bisa diterapkan oleh guru mata pelajaran lain untuk alternatif tingkatkan empati siswa, tetapi disesuaikan dengan modul pelajaran sebab tidak seluruh modul pelajaran bisa memakai metode role playing.

3. Bahwa dalam memberikan layanan Bimbingan dan Konseling terutama yang berkaitan dengan perilaku siswa hendaknya dicontohkan atau dipraktekkan melalui teknik role playing

\section{DAFTAR PUSTAKA}

Asri Budiningsih. (2004). Pendidikan Moral. Jakarta: Rineka Cipta.

Daniel Goleman. (1997). Emotional Intelligence. Jakarta: Rineka Cipta.

Hamzah B. Uno dan Nurdin Mohamad. (2011). Belajar dengan Pendekatan PAIKEM. Jakarta: PT Bumi Aksara.

Hansen. (1982). Menolong Menghindari Permasalahan Orang Lain dengan Metode Konseling. Yogyakarta: Pustaka Belajar.

Hisyam Zaini dkk. (2008). Strategi Pendidikan Aktif. Yogyakarta. Pustaka Insan Madani.

Ismail SM. (2008). Strategi Pendidikan Agama Islam Berbasis PAIKEM. Semarang: RaSAIL.

Oemar Hamalik. (2008). Proses Belajar Mengajar. Jakarta: Bumi Aksara.

Pangaribuan. (1993). Mengembangkan Empati Anak. Jakarta: Bumi Aksara.

Supardi. (2010). Strategi Pembelajaran Ilmu Pengetahuan Sosial. Diktat. Yogyakarta: FISE UNY.

Syaiful Bahri Djamarah serta Aswan Zain. (2006). Strategi Belajar Mengajar. Jakarta: Rineka Cipta.

T. Safaria. (2005). Metode Pengembangan Kecerdasan Interpersonal Anak. Yogyakarta: Amara Books 